\title{
IfIIISGUC.ORG
}

"İȘ, GÜC̣" ENDÜSTRi ilLișKiLERI VE INSAN KAYNAKLARI DERGISi

"IS, GUC" INDUSTRIAL RELATIONS AND HUMAN RESOURCES JOURNAL

\section{Kadınlarda Olası Kariyer Sonlandırma Nedenlerini Belirlemeye Yönelik Bir Ölçek Geliştirme Çalışması}

\section{The Development Of A Scale To Determine The Causes Of Possible Career Termination Of Women}

\author{
Tarık TOTAN \\ Arş. Gör./Dokuz Eylül Üniversitesi Eğitim Fakültesi Psikolojik \\ Danışmanlık ve Rehberlik Ab.D \\ Tayfun DOĞAN \\ Öğr. Gör./ Sakarya Üniversitesi Eğitim Fakültesi Psikolojik Danışmanlık ve \\ Rehberlik Ab.D
}

Ekim/October 2010, Cilt/Vol: 12, Say1/Num: 4, Page: 33-50 ISSN: 1303-2860, DOI: 10.4026/1303-2860.2010.0156.x

Makalenin on-line kopyasına erişmek için:

http://www.isguc.org/?p=article\&id=425\&vol=12\&num=4\&year=2010

To reach the on-line copy of article:

http://www.isguc.org/?p=article\&id $=425 \& v o l=12 \&$ num $=4 \&$ year $=2010$

Makale İçin İletişim/Correspondence to: 
(C) 2000- 2010

"İşGüç" Endüstri İlişkileri ve İnsan Kaynakları Dergisi

"İşGüç" Industrial Relations and Human Resources Journal

Ekim/October 2010, Cilt/Vol: 12, Say1/Num: 4

ISSN: 1303-2860, DOI: 10.4026/1303-2860.2010.156.x

Editör/Editor-in-Chief

Aşkın Keser (Kocaeli University)

Editör Yardımcıları/Co-Editors

K.Ahmet Sevimli (Uludağ University)

Gözde Yılmaz (Kocaeli University)

Uygulama/Design

Yusuf Budak (Kocaeli Universtiy)

\author{
Yayın Kurulu / Publishing Committee \\ Dr.Zerrin Firat (Uludăg University) \\ Doç.Dr.Aşkın Keser (Kocaeli University) \\ Prof.Dr.Ahmet Selamoğlu (Kocaeli University) \\ Yrd.Doç.Dr.Ahmet Sevimli (Uludağ University) \\ Yrd.Doç.Dr.Abdulkadir Şenkal (Kocaeli University) \\ Yrd.Doç.Dr.Gözde Yilmaz (Kocaeli University) \\ Dr.Memet Zencirkıran (Uludağ University)
}

Uluslararası Danışma Kurulu / International Advisory Board

Prof.Dr.Ronald Burke (York University-Kanada)

Assoc.Prof.Dr.Glenn Dawes (James Cook University-Avustralya)

Prof.Dr.Jan Dul (Erasmus University-Hollanda)

Prof.Dr.Alev Efendioğlu (University of San Francisco-ABD)

Prof.Dr.Adrian Furnham (University College London-İngiltere)

Prof.Dr.Alan Geare (University of Otago- Yeni Zellanda)

Prof.Dr. Ricky Griffin (TAMU-Texas AEM University-ABD)

Assoc. Prof. Dr. Diana Lipinskiene (Kaunos University-Litvanya)

Prof.Dr.George Manning (Northern Kentucky University-ABD)

Prof. Dr. William (L.) Murray (University of San Francisco-ABD)

Prof.Dr.Mustafa Özbilgin (University of East Anglia-UK)

Assoc. Prof. Owen Stanley (James Cook University-Avustralya)

Prof.Dr.Işık Urla Zeytinoğlu (McMaster University-Kanada)

Danışma Kurulu / National Advisory Board

Prof.Dr.Yusuf Alper (Uludağ University)

Prof.Dr.Veysel Bozkurt (Uludağ University)

Prof.Dr.Toker Dereli (Işık University)

Prof.Dr.Nihat Erdoğmuş (Kocaeli University)

Prof.Dr.Ahmet Makal (Ankara University)

Prof.Dr.Ahmet Selamoğlu (Kocaeli University)

Prof.Dr.Nadir Suğur (Anadolu University)

Prof.Dr.Nursel Telman (Maltepe University)

Prof.Dr.Cavide Uyargil (İstanbul University)

Prof.Dr.Engin Yildırım (Sakarya University)

Doç.Dr.Arzu Wasti (Sabancı University)

Dergide yayınlanan yazllardaki görüşler ve bu konudaki sorumluluk yazarlarına aittir.

Yayınlanan eserlerde yer alan tüm içerik kaynak gösterilmeden kullanılamaz.

All the opinions written in articles are under responsibilities of the outhors.

None of the contents published can't be used without being cited. 


\title{
Kadınlarda Olası Kariyer Sonlandırma Nedenlerini Belirlemeye Yönelik Bir Ölçek Geliştirme Çalışması
}

\author{
The Development Of A Scale To Determine The Causes Of Possible \\ Career Termination Of Women
}

\author{
Tarık TOTAN \\ Arş. Gör./Res. Assistant
}

\author{
Tayfun DOĞAN \\ Öğr. Gör./Lecturer
}

\begin{abstract}
Özet:
Ülkemizde kariyer değerlendirmeye yönelik kullanılan ölçeklerin büyük bir kısmı Batı dünyasından uyarlanmıştır. Ancak bu ölçeklerinin hemen hepsi Batıda yaşayan erkekler temel alınılarak geliştirildiği için kadınlara uygulandığında geçerliği ve güvenirliği tartışma konusu olmaktadır. Günümüzde kadınların kariyer gelişiminin ve kariyer sonlandırma nedenlerinin erkeklerden oldukça farkh olduğu görüşü giderek uzmanlarca kabul görmektedir. Bu araştırmada Cook, Heppner ve O'Brien (2005)'nin kadınlarm kariyer örüntülerinin temelinde etnik ve toplumsal cinsiyet rollerinin yer aldığını savundukları ekolojik modellere dayanan kadınlarda olası kariyer sonlandırma nedenleri ölçeğinin geliştirme çalışması yürütülmüştür. Ölçeğin geliştirilmesi çalışmasının ilk aşamasında alanyazın ve kü̧̈ük bir gruptan elde edilen nitel veriler aracllığıyla 25 maddelik bir madde havuz oluşturulmuştur. Uzman görüşlerinin ardından hazırlanan denemelik form 2007-2008 öğretim yılında Abant İzzet Baysal Üniversitesinde farkl fakültelere devam eden 356 kadın katılımcrya uygulanmıştır. Tek grup üzerinden yürütülen geçerlik ve güvenirlik çalışması sonrasında "çocuk sorumluluğu", "eşin önceliği" ve "iş yaşamı sorunları" olarak isimlendirilen 3 alt ölçekli 14 maddeli bir ölçek elde edilmiştir.
\end{abstract}

Anahtar Kelimeler: Kadın, kariyer sonlandırma, kariyer değerlendirme, geçerlik, güvenirlik

\begin{abstract}
:
Most of the scales to assess the careers are standardized from Western cultures' male population. Therefore, there becomes handicap when they are used for female population. Today, the career development and discontinuous causes of women are accepted as different from men. In this research, the development of a scale to determine the causes of possible career discontinuous of women is conducted, that is based on the ecological model of Cook, Heppener, and O'Brien (2005) in which they believe that the career patterns of woman are based on ethnic and social gender roles. During the first step, an item pool of 25 items is established by qualitative data obtained from literature and small groups of women. After the specialists' views, a pilot form is conducted to 356 women participants from Abant Izzet Baysal University during 2007-2008 education years. After the validity and reliability studies, a scale which consists of 14 items with 2 subscales, named as "responsibility of child", "spouse priority", and "work life problems".
\end{abstract}

Keywords: Woman, career discontinuous, career assessment, validity, reliability 


\section{Giriş}

Günümüzde modern yaşamin gereği olarak kadınların iş yaşamında daha fazla yer aldıklarını görmekteyiz. Gazetelerde sıklıkla profesyonel mesleğe sahip kadınlara yönelik iş ilanlarının da olduğu görmek bunun kanıtı olarak değerlendirilebilir. Kariyer gelişimini açıklayan birçok kuram erkek katılimclardan elde edilen veriler doğrultusunda oluşturulmuştur (Cook, Heppner ve O'Brien, 2002). Oysa kadınların kariyer gelişiminin erkeklerin kariyer gelişiminden oldukça farklı ve karmaşık olduğu bilinmektedir (Bierema, 1998). Bunun yanı sıra kadınların kariyer seçimi, üstlendikleri yaşam rolleri ve kariyer beklentileri de erkeklere benzememektedir (Schreiber, 1998). $\mathrm{Bu}$ gibi sebeplerden günümüzdeki çoğu araştırma ve kuram erkekler göz önüne alınarak yapılandırıldığ 1 için kadınların kariyer gelişimini açıklamaktan oldukça uzaktır. Toplumsal cinsiyet rollerinin etkisi ve kad1nın evle iş hayatı arasındaki sorumluluklarını dengeleyememesi onun kariyerine hiç başlayamamasına ya da başladığ $\breve{1}_{1}$ kariyerini çok erken sonlandırmasına neden olmaktadir.

Çalışma yaşamının ayrılmaz bir parçası olan kadınların erkeklere oranla baş etmesi gereken birçok sorunla birlikte birçok yaşamsal rolü de bulunmaktadır. Çağımız kadını ataerkil örgütler içinde hem anne hem çalıșan hem de eş sorumluluklarını üstlenirken aile ve iş arasında bocalamalar yaşamaktadır. Bu gibi sorunlar kadınların yarı zamanlı işlere ya da yeterliliklerinden daha az yeterlilik gerektiren işlere yönelmelerine neden olmaktadır. Yapılan araştırmalara göre tam zamanlı işlerde çalışan kadınlar erkeklere oranla daha az kazanmakta, yönetimde daha az yer almakta ve kariyerlerinden daha az tatmin olmaktadırlar (Bierema, 1998). Kadınlar çalışma hayatına geçmişe oranla daha çok katılmakla birlikte kadınların olanakları, firsatları toplumun geleneksel bakışından etkilenerek evde ve işte çatışma yaşamalarına neden olmaktadır (Schreiber, 1998).

Ülkemizdeki hızla gelişen eğitim olanak- larıyla birlikte daha çok birey eğitim almaya başlamıştır. Ancak mezun olan profesyonel meslek sahibi bireylerle onların istihdamı arasında doğru orantı kurmaya çalışmak neredeyse imkânsızdır. Bu sınırlı sayıdaki işe birey yerleştirmeye çalışan uzmanların kullandıkları ölçme aracı sınırlıdır. Hali hazırda var olan ölçme araçları ise Batı dünyasını temsil etmekle birlikte toplumumuzun bireye dönük kültürel yargılarını içermekten uzaktır. İlköğretim ve ortaöğretim kurumlarında hızla yaygınlaşan psikolojik danışmanlık mesleği yakın zamanda hızla yükseköğretim kurumlarında ve kariyer merkezlerinde yaygınlaşmaya başlamıştır. Kariyer psikolojik danışmanlığ 1 alanın da psikolojik danışmanların yaygınlaşmaya başlaması doğru işe doğru kişiyi yerleştirme imkânı sunmakla birlikte zaman ve işgücü kaybını da azaltacaktır. Bu araştırmanın amacı kariyer psikolojik danışmanlığı alanında kullanılmak üzere üniversite mezunu, profesyonel meslek sahibi kadınların ilerideki olası kariyer sonlandirma nedenleri belirmeye yönelik bir ölçek geliştirmektir.

\section{Kadınların Kariyer Sonlandırma Nedenleri}

Endüstri çağından bilgi çağına geçildikçe iş yaşamı ve çalışma alanları da değişim göstermiştir. Buna bağlı olarak kadınların kariyer gelişimi de değişmekte ve daha da karmaşıklaşmaktadır. Günümüzde işverenler bu farklılıkları kazanca dönüştürmenin yollarını arasalar da henüz kadınların tam olarak işgücünde yer aldığ 1 ABD'de dahi söylenememektedir (Bierema, 1998). Kadınların erkeklere oranla kariyer kesintisine ve kariyer sonlandırmasına daha yatkın olduğu bilinmektedir. Kariyer sonlandırmayı açıklayan çoğu kuram ise sadece erkekler temel alınarak ortaya çıktığı için kadınların kariyer sonlandırma nedenlerini açıklamaktan oldukça uzaktır. Kadınların kariyer gelişimini açıklayan birkaç kuram bireysel farklılıklardan ve kültürel duyarlılıklardan yoksun olarak "bir beden hepsine olur" (one size fits all) mantığıyla bazı araştırmacılarca kabul görmektedir (Bierema, 1998). Bu durum kadınların kariyer gelişimleri içerisindeki kari- 
yer sonlandirma nedenlerine de yansiyarak onların kariyerlerine neden devam etmedikleri sorusuna yanıt vermeyi imkânsız kılmaktadır. Kariyer gelişimini açıklayan kuramların sorunlarından biri kariyer basamaklarını bir üst basamağa geçmek için gerekli psikolojik gereksinimleri ya da gelişimsel görevleri tamamlama olarak değerlendirilmesidir. Oysa günümüzde kariyer birey için birçok firsatın olduğu gerektiğinde başka olanakları da sunan bir döngü haline gelmiştir (Smart, 1998). Örneğin işletme mezunu bir birey sayısız iş imkânından faydalanarak bir işe başlayıp o işteki en üst kademeye ulaşabileceği gibi belli bir süre sonra bu işi bırakıp başka bir işte çalışmaya da başlayabilir. Bireyin işler arasındaki bu hareketliliği klasik kariyer kuramları açıklayamamaktadır.

İş ve kişisel yaşam arasındaki çatışma; çalışma saatlerinin çokluğundan, ağır iş yüklerinden, hafta sonu çalışmanın gerekliliğinden, sık sık şehir dişı seyahatlerin olmasından, çalışma saatlerine müdahale etmenin zorluğundan, güvensiz bir işe sahip olmaktan, işte elde edilecek gelirin farklılık göstermesinden, işten çıkarılmalardan, işin fiziksel ve psikolojik yükünün çokluğundan, işyerindeki huzursuzluklardan, yardımcı çalışan olmamasından, yönetici ile sorunlardan ve çalışma şartlarının esnek olmamasından kaynaklanabilmektedir (Friedman, 1991; akt. Wenling, 1998). Ayrica kadınların kariyer planları ve eğitimleri onların annelik rolleri, sosyal baskı ve çocuklarının bakımıyla ilgili sorumlulukları gibi değişkenlerden etkilenmektedir. ABD.'deki eğitim olanaklarında kadınlar ve erkekler arasında ayrımcılık söz konusu olmadığı belirtilirken kadınların annelikle ilgili algıları onların gelecekteki kariyer olanaklarını etkilemektedir.

Eğitim esnasında kadınlar ve erkekler iş, evlilik, aile ve ev işleri rollerinin eşit öneme sahip olduğunu belirtmekle birlikte işle ve yaşamla ilgili kişisel umut ve inançları aile kurduktan sonra üstlenilen eş ve ebeveyn sorumluluklarıyla birlikte geleneksel görüşün ortaya çıkmasına neden olmaktadır
(Marks ve Houston, 2002). Böylece kadınlar erkeklere oranla ev ve çocuklarıyla ilgili daha çok sorumluluk üstlenmektedirler. Hatta geleneksel yaklaşımın etkisiyle kadınların ev ve çocuk bakımıyla ilgili sorumluluklarından dolayı yarı zamanlı işlerde çalışması gerektiğini savunan araştırmacılar bulunmaktadır. Bu görüşe dayanak olarak da kadınları kariyerlerini devam ettirmeyi sağlaması, profesyonel kimlik kazanmalarını sağlaması, profesyonelliklerini ve becerilerini geliştirmelerini devam ettirmesi, tam zamanlı işe dönmelerinde kolaylık sağlaması, kadının ekonomik güvencesi olması, iş ve evle ilgili sorumlulukları arasında denge sağlaması açısından fayda sağlayacağı belirtmektedirler (Brumit Kropf, 1998).

Her ne kadar kadınla erkeğin çalışma hayatındaki statüleri eşitleniyormuş gibi alg1lansa da durumun tam olarak eşitlendiği söylenemez. ABD. İş Gücü İstatistik Bürosunun (U.S. Bureau of Labor Statistics) 1998 verilerine göre çalışan her erkeğin 1 Dolarlık kazancına karşılık bir kadın 68 Cent kazanırken bu oran yönetim için 1 Dolara 74 Cent olarak raporlanmıştır. Ayrıca en çok kazanan 500 kişinin açıklandığ 1 Fortune listesinde ise sadece 61 kadın yer almaktadır. Aynı verilerde ABD'de 5-6 yaşlarında çocuğu olan evli kadınların \%76'sının, 6 yaşından küçük çocuğu olan kadınların ise \%64'ün çalıştığı bulgulanmıştır (Bierema, 1998; Wentling, 1998). ABD.'de kadının çocuk ve ev işlerini, erkeğin ise para kazanma ve geçim sorumluluklarını yüklendiği geleneksel aile tipi sadece \%10 düzeyindedir. Buna karşın hala kadının kazanc1 ekstra gelir veya aile ekonomisine ek destek olarak algilanmaktadır (Wentling, 1998).

Kadınların kariyer gelişimini başlı başına açıklamaya çalışan bütüncül bir kuram henüz bulunmamaktadır. Geleneksel kuramlar ise kadınların mesleki davranışlarını ve yaşantılarını açıklamakta yetersiz kalmaktadır (Schreiber, 1998). Günümüzde işe girmeyle ilgili kariyer yapıları erkekler için düzenlenmiştir (Brumit Kropf, 1998). Kadınlar kariyer gelişimi için; plan yapma, kariyer 
eğitimi alma, danışman bulma, geri dönüt alma, hata yapma ve hatadan öğrenme, deneyimi kazanca aktarabilme, ayrımcılık ve şiddetle baş etme, iş değiştirme, kültürün olumsuz etkisini hafifletme, iş ve kişisel yaşam arasında denge kurma gibi sorunlarla mücadele etmek zorundadır (Bierema, 1998). Kadınlar, kariyerlerine ilişkin kararları verirken kariyer danışmanlığı ve yönetimi hizmetlerini eksik olarak aldıkları için örgüte uyum sağlamada sorun yaşamaktadırlar (Bierema, 1998; Brumit Kropf, 1998). Ayrica kadınlar erkeklere oranla daha fazla mesleki kararsızlık yaşamaktadırlar (Aytaç ve Bayram, 2001).

Bir işte çalışmak öncelikle bireyin gelir elde etmesini sağlamakla birlikte bunun yanı sıra bireyin statü kazanmasını, mesleki kimlik duygusu geliştirmesini, sosyal çevreyle etkileşimde bulunmasını ve saygınlık kazanmasını da sağlanmaktadır (Aytaç, 2001; Aytaç ve Keser, 2002). Bir işte çalışmayı en çok etkileyen unsur ise bireylerin meslek hayatları boyunca karşılaştıkları kariyer engelleridir. Yapılan araştırmalar kadınların erkeklere oranla daha fazla kariyer engelliyle baş etmesi gerektiğini göstermektedir (Hawley McWhirter, 1997). Kadınların kariyer gelişimindeki engeller; toplumun meslekler hakkında basmakalıp yargıları, hata yapma korkusu, başarı korkusu ve düşük öz yeterlilik düzeyinin ilk çocukluk döneminde kızlara sosyal çevresi tarafından kanıksatılması nedeniyle kadınlar kariyer gelişimlerinde ciddi sorunlar yașamaktadır (Herr ve Cramer, 1996: 270-271). K1z ve erkek çocuklarının aileleri, öğretmenleri, akranları ve kendisini yetiştirenlerin dini inanışları onların bazı sosyalleşme kalıpları içinde yetiştirilmeleri neden olmaktadır. Bu durum kadınlar için başka bir kariyer engeli olarak kendini göstermektedir (Gysbers, Heppner ve Johnston, 1998: 59).

Kadınlar eşit kariyer olanaklarına sahip olsalar bile erken yașlardan itibaren henüz okulda eğitim aldıkları dönemde bile kariyerlerini bitirmeye yönelik fikirlere sahip oldukları belirtilmektedir (Marks ve Houston, 2002). Bu durumda, erken çocukluk döne- minde oluşan toplumsal cinsiyet rollerinin etkisi olduğu düșünülebilir. Örneğin yetişkinler çok küçük yașta erkek çocukları inşaatla ilgili oyuncaklarla oynamasını teşvik ederken kızların da oyuncak bebekle oynamasını teşvik etmektedir. Bu durum, kızların kimlik gelişiminde bilim, mühendislik ve teknoloji alanlarının erkeklere oranla daha az gelişmesine neden olmaktadır. Farkında olmadan sosyal çevreleri kız çocukları akademik kariyer ve karar verme sürecinde bilim, mühendislik ve teknoloji alanları için cesaretlendirmemektedir (Marks ve Houston, 2002).

Kadınlar çalışma hayatları boyunca erkek merkezli işlerde çalıştıkları için gerçek becerileri gösterememekte ve becerilerinin altında işlerde çalışabilmektedirler (Mott, 1998). ABD.'de 16-65 yaş arasındaki kadınların \%65'i, İsveç'te \%78'i, Kanada'da \%63, $5^{\prime}$, İtalya'da \%43'ü ve İrlanda'da \%38'i çalışmaktadır (Herr ve Cramer, 1996: 258). Ancak çalışma alanlarında erkeklere ve kadınlara has mesleklerin olduğu düşüncesi toplumda hala etkisini devam etmektedir. Örneğin Amerikan Çalışma Bakanlığının 1999 verilerine göre (Sharf, 2002) mühendislerin \%11'i ve tamircilerin \%4'ü kadınken hemşirelerin ancak $\% 7,5^{\prime}$ u sekreterlerin ise $\% 7,4^{\prime}$ ü erkek olduğu bulunmuştur. Günümüzde her ne kadar kadınlar erkeklerle eşit eğitim olanaklarına sahip olsalar da mühendislik, fizik, kimya, bilgisayar teknolojileri ve diğer benzer alanların çalışma ortamında oldukça az yer almaktadirlar (Rosenbloom, Ash, Dupont ve Coder, 2007). Ülkemizde kadınların çalışma hayatında katılma oranları daha da düşük düzeylerdedir. TÜİK (2009)'in hane halkı işgücü anketi sonuçlarına göre Türkiye'de Ekim 1988'de kadınların \%34,3'ü herhangi bir meslekle veya beden gücüyle çalışma hayatında yer alırken bu oran Mayıs 2008'de \%26,6'ya gerilemiştir. Bu 20 yıllık süreç içerisinde kadınların iş gücüne katılma oranın giderek azaldığı görülmektedir.

ABD'de yapılan araştırmalara göre çal1şan kadınların \%37'si aileleriyle daha çok zaman geçirmek, yarıda kalan eğitimlerine devam etmek, işlerinden memnun olmadık- 
larından dolayı, başka bir yere taşınmaları gerektiği için ve farklı bir işte çalışmak istedikleri için işlerinden ayrılmaktadırlar (Hewlett ve Luce, 2000). Kariyerlerinde en verimli yıllar olan orta yaştaki kadınların kariyerlerini sonlandırma nedenleri olarak sağlık sorunları, az kazanmaları ve hayatlarının kalanında farklı yaşama isteği olduğu belirtilmektedir (Mott, 1998).

Ülkemizde kadınların kariyer sorunlarıyla ilgili yapılan sınırlı sayıdaki araştırma konusu genellikle bazı sektörler de çalışan kadınların sorunları üzerinde yoğunlaştığı görülmektedir. Kocaeli'nde yürütülen bir araştırmanın bulgularına göre (Pınarcıoğlu, 2006); kadınların eğitim düzeyi arttıkça iş gücüne katılma isteği artmaktadır. Araştırma bulgularına göre çoğunluğu düşük düzeyde eğitim seviyesine sahip kadınlar (okuma yazma bilmeyen, ilkokul, ortaokul mezunu; $\mathrm{n}=66$ ) çalışmak istemediklerini belirtirken üniversite mezunu kadınların hiç biri çalışmak istemediğini belirtmemiştir $(\mathrm{n}=$ 53). Asgari ücretle - 2.000 TL. arasında maaş alan kadınlar incelendiğinde maaş artıkça kadınların çalışmak istememe eğiliminin de arttığı raporlaştırılmıştır. Aynı araştırma da kadınlar işsiz kalma nedenleri olarak yetersiz eğitim almayı \%37, aracı bulamamayı $\% 84$, evli olmay $\% 19$, kadın olmay $\% 26$, işin gerektirdiği yaşta olmamay $\% 20$, deneyimi olmamay $\% 26$ ve iş yaşamina ara vermiş olmayı \%12 oranında çok etkili olarak değerlendirilmiştir. Kadınlar çalışmama nedeni olarak ise evim iş yükü, çalışmaktan yorulmak, aile/eşin izin vermemesi, çalışma koşullarının ağır olması, yetersiz eğitim ve kendi tercihi gibi nedenlere bağlamışlardır.

Cook, Heppner ve O'Brien (2005) kadınların kariyer örüntülerini açıklamak için insan davranışlarının temelinde etnik ve toplumsal cinsiyet rollerinin yerleştiğini savundukları ekolojik bir model geliştirmişlerdir. Bu model Kurt Lewin'in insan davranışlarını açıklayan kişinin çevresiyle bütünleşme çabasında olduğuna ilişkin açıklamalarına dayanmaktadır. Araştırmacılara göre insan, doğası gereği sosyal çevresi ile bütünleşme çabasındadır. Ayrıca kadınlar erkeklere oranla daha sosyal oldukları için toplumun dayattığ1 rolleri kabul etmeye daha çok yatkındırlar. Dolayısıyla kadınların kariyer gelişimi değerler, gelenekler ve toplumsal kurallar gibi kültürel içerikten etkilenerek şekillenmektedir. Bu araştırma da Cook, Heppner ve O'Brien (2005)'in ekolojik modeline dayanan kadınların olası kariyer sonlandırma nedenlerini belirlemeye yönelik bir ölçek geliştirilmesi hedeflenmiştir.

\section{Yöntem}

Bu bölümde kadınlarda olası kariyer sonlandırma nedenleri ölçeğinin geliştirilmesinde izlenen yol, katılımcllar ve istatistiksel analizlere ilişkin işlem yollarını açıklayan bilgiler yer almaktadır.

\section{1 Ölçek maddelerinin yazılması ve deneme formunun hazırlanması}

Kadınlarda olası kariyer sonlandırma nedenlerini belirmeye yönelik ölçek geliştirme çalışmasında DeVellis'in önerdiği (2003: 6096) ölçek geliştirme yaklaşımı kullanılmıştır. Bu yaklaşıma göre öncelikle neyin ölçülmek istendiğinin açıkça belirlenmesi gerekmektedir. Daha sonrasinda madde havuzunun oluşturulması, ölçeğin türünün belirlenmesi, maddeler için uzman görüşü alınması, kapsam geçerliğinin yapılması, ölçeğin uygulanması, maddelerin değerlendirilmesi ve ölçeğin en uygun hale getirilmesi basamakları yer almaktadır. Bu basamakları izlemek amacıyla öncelikle ölçek maddelerine ilişkin havuz oluşturulmuştur. Madde havuzu oluşturulmak amacıyla alan yazın taraması sonucunda Cook, Heppner ve O'Brien'inin (2005) kadınların kariyer gelişiminin etnik ve toplumsal cinsiyet rollerinden etkilediğini vurguladıkları ekolojik yaklaşımlarına ulaşılmıştır. Clark ve Watson (1995) bir ölçme aracı geliştirirken kuramsal çerçevenin olmasını salık vermektedirler. Bu amaçla ölçeğe ilişkin maddeler Cook, Heppener ve O'Brien'inin ekolojik yaklaşımına dayand1rılmıştır. Aynı zamanda üniversite öğrencisi 20 kadından oluşan bir çalışma grubuna kadınların neden işlerine son verdiklerini ve 
çevrelerindeki örnekleri açıklamalarına yönelik açık uçlu sorular sorularak bu sorulara yanıtlarını yazmaları istenmiştir. İlgili alanyazın taraması ve çalışma grubundan elde edilen veri sonucunda kadınların işlerini bırakma nedenleri olarak; eşle ilgili nedenler, çocukla ilgili nedenler, maddi kazanca ihtiyaç olmaması veya evin geçimini erkeğin yüklenmesi ve toplumsal cinsiyet rolleri gibi boyutlar belirlenmiştir. Yürütülen çalışmalar sonrasında kadınların olası kariyer sonlandırma nedenleri olarak belirlenen boyutları içeren 30 madde oluşturulmuştur. Oluşturulan bu maddeler Psikolojik Danışma ve Rehberlik alanında 2 öğretim üyesine kapsam geçerliliği açısından inceletilmiştir. İnceleme sonrasında konu alanından uzak olduğu düşünülen 3 madde deneme formundan çıkarılmıştır. Geride kalan 27 madde Türk Dili uzmanı olan 2 öğretim elemanına inceletilmiştir. İnceleme sonrasında birbirine çok yakın ifadelendirilmiş 4 madde olduğu belirlenmiştir. Bu 4 madde 2 maddeye indirilerek toplamda 25 maddelik 5'li Likert tipi (Hiç uygun değil, çok az uygun, kısmen uygun, oldukça uygun, tamamen uygun) denemelik form oluşturulmuştur.

\subsection{Araștırmanın katılımcıları}

Araştırma katılımcıları 2007-2008 öğretim y1lında Abant İzzet Baysal Üniversitesinde 3. sinifa ( $n=174, \% 48,88)$ ve 4 . $\sin 1 f a(n=182$, $\% 51,12$ ) devam eden yaş ortalaması 22 olan toplamda 356 bayan öğrenciden oluşmaktadır. Katılımcıların \%44,5'i Eğitim (n=159), $\% 29,4$ 'ü Fen (n= 105), \%14,8'i İktisat (n= 53), $\% 2,8^{\prime}$ i Mühendislik Fakültesi, \%3,9'u Beden Eğitimi (n=14) ve \%4,2'si (n=15) Hemşirelik Meslek Yüksek Okulu öğrencisidir. Üniversiteye yerleşmeden önce araştırmaya katılan öğrencilerin \%61,60'1 şehir merkezlerinde $(n=220), \% 388^{\prime} 40^{\prime} 1$ ise köy veya kasabada yaşarken( $n=136)$ üniversiteyi kazandıklarını bildirmişlerdir.

\section{3 İşlem}

Araştırmanın amacına uygun olarak geliştirilen denemelik form, yönerge ve kat1lımcıların kişisel bilgilerini belirmeye yönelik oluşturulan formla birlikte araştırma katılımcıları tarafından doldurulmuştur. Elde edilen veri seti öncelikle veri önişleme yöntemleri aracılığıyla analizlere uygunluk acısından incelenmiştir. Oğuzlar (2003) bir verinin istatistiksel olarak analize alınmadan önce gürültülü değerler (noising values) ve boş veriler (missing values) açısından incelenmesi gerektiğini belirtmektedir. $\mathrm{Bu}$ amaçla önce verideki gürültülü veriler belirlenmiş ve veri setine geri dönülerek belirlenen sorunlar giderilmiştir. Her ne kadar araştırma verisindeki boş değerler \%5' in altında olarak belirlense de doğrulayıcı faktör analizinde boş değerlerin sorun olabileceği düşünülerek boş değerlere E-M (EstimationMethods) kullanılarak veri ataması yapılarak veri istatistiksel analizlere hazır duruma getirilmiştir (Tabachnick ve Fidell, 2007: 68). İşlem yolunun bir sonraki aşamasında yapı geçerliği çalışması yürütülmüştür. Ölçeğin yapı geçerliliği çalışmasında betimleyici faktör analizi ve doğrulayıcı faktör analizi yöntemleri kullanılmıştır. Betimleyici faktör analizi araştırmacıya maddelerinin hangi faktörler altında yüklendiği incelemesine olanak verirken (Coakes, 2005: 154) doğrulayıcı faktör analizi ise araştırmacının oluşturduğu modelin veri tarafindan doğrulanma düzeyini inceleye yöneliktir (Noar, 2003). Araştırmacılar çoğu ölçek geliştirme çalışmalarında betimleyici faktör analizinin sonrasında doğrulayıcı faktör analizini kullanma eğilimindedirler (Worthington ve Whittaker, 2006). Bu araştırma da betimleyici faktör analizinin sonrasında doğrulayıcı faktör analizi kullanılması benimsenmiştir. Bunun için öncelikle verilerin betimleyici ve doğrulayıc faktör analizlerinin yapılabilmesi için gerekli kıstasları taş1yıp taşımadığ 1 incelenmiştir. Araştırma verisinin tüm maddelerde normal dağılım (Kolmogorov Smirnov p > ,050) ve doğrusallık gösterdiği gözlenmiştir (Tabachnick ve Fidell, 2007: 613). Ayrıca ölçek maddelerinin her birinde (univariate) ve madde birleşimlerinde (multivariate) aykırı değerler (outlier) incelenmiştir (Hair, Black, Babin, Anderson ve Tatham, 2006: 74-76; Tabachnick ve Fidell, 2007: 72-77). Betimleyici faktör 


\section{Şekil 1}

\section{Betimleyici faktör analizi sınama grafiği}

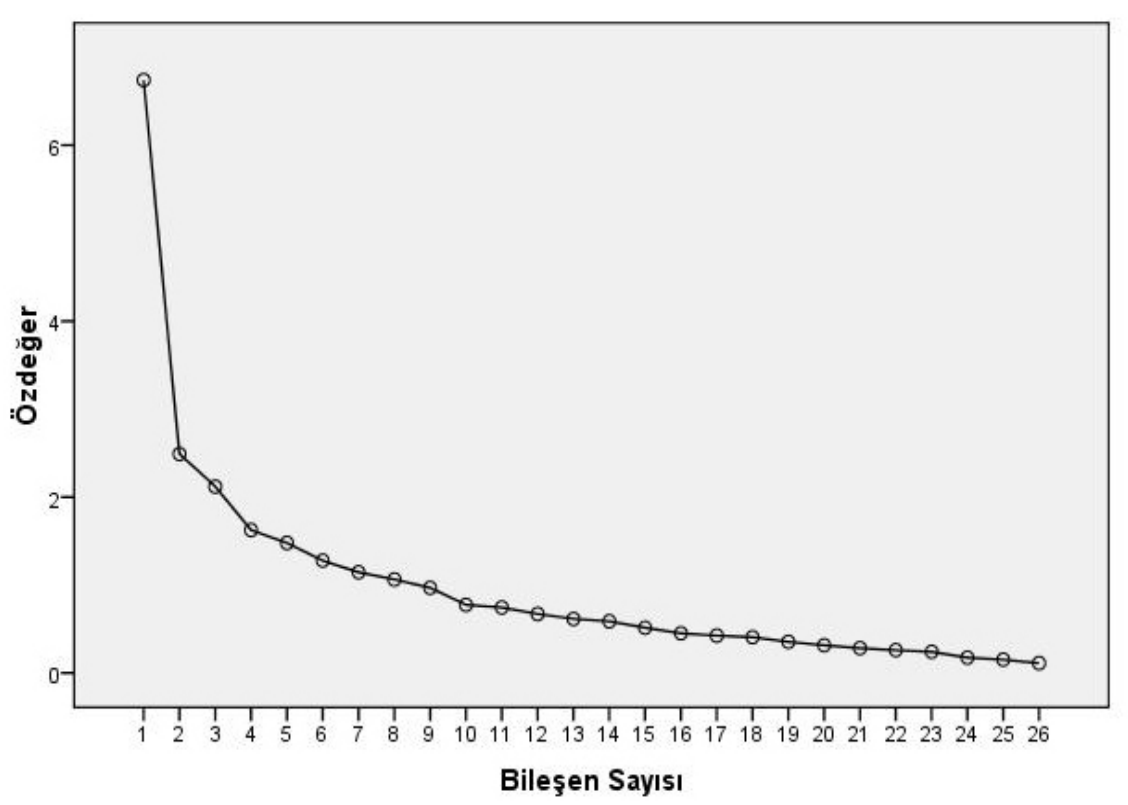

analizi için 300 katılımcıdan toplanan verinin (Comrey ve Lee, 1992: akt. Tabachnick ve Fidell, 2007: 613) yapısal eşitlik modellerinde ise 200 katılımcının üstünde olan verinin yeterli olduğu (Kline, 2005: 110) belirtmektedir. Bunun içinde araştırma katılımcılarının yeterli düzeyde olduğu kabul edilmiştir. Bu ölçütlerin yanı sıra doğrulayıcı faktör analizi için uyum iyiliği indekslerinin yeterli düzeyler de olup olmadığ 1 incelenmiştir (Schumacker ve Lomax, 2004: 79-122; Raykov ve Marcoulides, 2006: 38-51). Ölçeğin geçerlik çalışmalarından sonra güvenirlik çalışmaları yürütülmüştür. Güvenirlik çalışmasında ölçeğin alt boyutlarının iç tutarlılık ve test tekrar test yöntemiyle ölçeğin kararlılık düzeyi sınanmıştır. Güvenirlik çalışması sonrasında madde analizi çalışması yürütülmüştür. Ölçeğe ilişkin maddeler madde toplam korelasyonları, alt/üst \%27'lik grup ortalamalarının karşılaştırması yöntemleriyle incelenmiştir (Büyüköztürk, 2007: 167-182). Araştırma kapsamında yapılan istatistiksel analizlerin tümü SPSS ve LISREL paket programları kullanılarak yapılmıştır.

\section{Bulgular}

Bu bölümde kadınlarda olası kariyer sonlandırma nedenlerini belirlemeye yönelik ölçek geliştirmeye yönelik araştırmanın bulguları yer almaktadır.

\subsection{Yapı geçerliği}

Betimleyici faktör analizi; Kadınlarda olası kariyer sonlandırma nedenleri ölçeğinin (KOKSNÖ) yapı geçerliğinin ilk aşaması ölçek maddelerinin hangi faktörler altında toplandığ 1 belirleyebilmek amacıyla betimleyici faktör analizinde temel bileşenler analizi (principal componants) yapilarak gerçekleştirilmiştir. Öncelikle betimleyici faktör analizinde dik döndürme tekniği kullanılarak öz değeri (Eigenvalue) 1'in üzerinde olan faktörleri belirlenmiştir. Analiz sonucunda özdeğeri 1'in üzerinde olan ve toplamda varyansın \%69'unu açıklayan 9 faktör olduğu bulunmuştur. Sınama grafiği (Scree plot) incelendiğinde 3. faktörden sonra açık bir kırılmanın olduğu gözlenmiştir (Bknz. Şekil 1). 
Sınama grafiğinde belirgin bir kırılmanın olduğu gözlendiği için betimleyici faktör analizinin bir sonraki aşamasında analiz 3 faktör üzerinden sınırlandırılarak tekrarlanmiştır. İkinci betimleyici faktör analizine ilişkin Kaiser Meyer Olkin (KMO) katsayıs1 .77 olarak hesaplanırken Barlett Spehericity testi

2 değeri 1228,854 $(\mathrm{p}<000)$ olarak hesaplanmiştır. Field (2005: 652) KMO katsayısının .50'nin üzerinde değer almasının Barlett Spehericity katsayısının ilişkin önem düzeyinin ise ,050'in altında olmasının gerektiği belirtmektedir. Her iki kriterinin analiz için karşılandığ1 gözlenerek betimleyici faktör analizi sonucunun yorumlanabilir olduğu kabul edilmiştir. Böylece sınırlandırılmış betimleyici faktör analizi sonucunda faktör yükleri .464- .817 arasında değişen, toplamda varyansın \%43,44'ünü açıklayan 14 madde belirlenmiştir. Faktör yükleri negatif yönde yüklenen veya .40'in altında kalan 11 maddenin ise ölçekten çıkarılmasına karar verilmiştir. Ölçeğin maddelerine ilişkin faktör ortak varyansları ve madde yükleri Tablo 1 'de sunulmuştur.

Üç faktöre sınırlandırılmış betimleyici faktör analizi sonuçları incelendiğinde birinci faktörde faktör yükleri .538 - .761 arasında değişen varyansın \%25,60'ını açıklayan 4 maddenin olduğu, ikinci faktörde madde yüklerinin .464 - .746 arasında değişen varyansın \%9,39'unu açıklayan toplam 5 maddenin, üçüncü faktör de ise faktör yükleri .473 - .817 arasında değişen ve varyansın \%8,45'ini açılayan 5 maddenin yer aldığı görülmektedir. Üç faktörün altında yüklenen maddeler incelendiğinde birinci faktör altında çocuk sahibi olmayı düşünme ve çocuk sahibi olma sonrasında kariyeri sonlandırmaya ilişkin maddelerin kümelendiği görülmektedir. Bunun içinde birinci faktöre "çocuk sorumluluğu" isminin veril-

Tablo 1

Üç faktöre sınırlandırılmış betimleyici faktör analizi

\begin{tabular}{|c|c|c|c|c|}
\hline Maddeler & $h^{2}$ & $\begin{array}{c}\text { Faktör } 1 \\
\text { Çocuk } \\
\text { sorumluluğu }\end{array}$ & $\begin{array}{l}\text { Faktör } 2 \\
\text { Eşin } \\
\text { önceliği }\end{array}$ & $\begin{array}{l}\text { Faktör } 3 \\
\text { İş yaşamı } \\
\text { sorunları }\end{array}$ \\
\hline Madde1 & ,761 & ,761 & & \\
\hline Madde14 & 667 & 731 & & \\
\hline Madde4 & 750 & ,572 & & \\
\hline Madde13 & ,827 & ,538 & & \\
\hline Madde12 & 669 & & ,746 & \\
\hline Madde7 & 632 & & 738 & \\
\hline Madde5 & 682 & &, 582 & \\
\hline Madde3 & 697 & & ,565 & \\
\hline Madde10 & 632 & & ,464 & \\
\hline Madde8 & 743 & & & 817 \\
\hline Madde6 & 681 & & & ,802 \\
\hline Madde9 & 692 & & & ,586 \\
\hline Madde11 & 652 & & & ,555 \\
\hline Madde2 & ,627 & & & ,473 \\
\hline $\begin{array}{l}\text { Açıklanan } \\
\text { varyans }\end{array}$ & & $\% 25,60$ & $\% 9,39$ & $\% 8,45$ \\
\hline $\begin{array}{l}\text { Açıklanan toplam } \\
\text { varyans }\end{array}$ & & & & $\% 43,44$ \\
\hline
\end{tabular}




\section{Tablo 2}

DFA modelinin uyum iyiliği indeksleri

\begin{tabular}{lllllllll}
\hline$\chi^{2}$ & sd & GFI & NFI & RFI & CFI & RMR & IFI & RMSEA \\
\hline 222,68 & 72 & 0,92 & 0,92 & 0,91 & 0,94 & 0,065 & 0,94 & 0,077 \\
\hline
\end{tabular}

mesi uygun görülmüştür. İkinci faktördeki maddelerin eşin iş önceliğine ilişkin basmakalıp yargıları içeren maddelerin yer aldığı görülmektedir. Bu durum göz önüne alınd1ğında ölçeğin ikinci faktörüne "eşin önceliği" ismi verilmiştir. Son olarak üçüncü faktör incelendiğinde ise kadının çalışma hayatında karşılaşabileceği olası sorunlarla baş etmek yerine kariyerini sonlandırmayı tercih etmesine yönelik maddelerin yer aldığ 1 görülerek bu faktöre de "iş yaşamı sorunlar1" isminin verilmesi uygun görülmüştür.

Doğrulayıcı faktör analizi; betimleyici faktör analiziyle belirlenen üç faktörün araştırma verisi tarafından doğrulanma düzeyi doğrulayıcı faktör analiziyle incelenmiştir. Yapı geçerliğinin bu aşamasında kadınlarda olası kariyer sonlandırma nedenleri ölçeğine ilişkin oluşturulan ikinci düzey (high order) model doğrulayıcı faktör analizi kullanılarak sınanmıştır. İkinci düzey doğrulayıcı faktör analizi sonucunda modifikasyon önerileri Madde1-Madde14 ile Madde12Madde7 arasındaki ilişkilerin modelin ki kare değerini önemli oranda düşürdüğü görülmüştür. Madde1 ile Madde14 ilişkin ifadeler incelendiğinde her iki ifadenin anlam olarak oldukça yakın olduğu görülmüştür. Aynı durumun Madde12 ile Madde7 arasinda da olduğu kabul edilerek modelin uyum iyiliği indekslerine katkı sağlamak amacıyla ilgili maddelerin hataları birbirleriyle ilişkilendirilmiştir. Bu ilişkilendirme sonrasında model tekrar analize alınmıștır.

Modelin uyumuna ilişkin ilk inceleme ki kare katsayısının serbestlik derecesine oranı aracılığıla incelenmiştir $(222,68 / 72=3,10)$. Bu oranın 5'ten küçük olması, modelin kabul edilebilir olduğunu göstermektedir (Şimşek, 2007: 14). Nihai modelin ki kare değerinin serbestlik derecesine oranı 3,10 olarak hesaplandığ 1 için modelin yeterlilik gösterdiği düşünülebilir. Ancak bu oran tek başına yeterli değildir. Bunun içinde modele ilişkin uyum iyiliği indeksleri (goodness of fit indexes) incelenmesi gerekmektedir. Bu araştırmada uyum iyiliği indeksleri olarak ki kare uyum testi (chi-square goodness), uyum iyiliği indeksi (goodness of fit index, GFI), standartlaştırılmış uyum indeksi (normed fit index, NFI), göreli uyum indeksi (relative fit index, RFI), orantilı uyum indeksi (comparative fit index, CFI), ortalama hataların karekökü (root mean square residuals, RMR), fazlalık uyum indeksi (incremental fit index, IFI) ve yaklaşık hataların ortalama karekökü (root mean square error of approximation, RMSEA) indeksleri kullanılmıştır. Araştırmacılar GFI, NFI, RFI, CFI ve IFI indekslerine ilişkin değerlerin .90'dan büyük RMSEA değerinin ise .08'den küçük olmasının yeterli olduğu belirtilmektedirler (Schumacker ve Lomax, 2004: 79-112; Meyers, Gamst ve Guarino; 2006: 559; Raykov ve Marcoulides, 2006: 38-51; Şimşek, 2007). Tablo 2'ye bakıldığında modele ilişkin tüm uyum iyiliği indekslerinin yeterlilik gösterdiği görülmektedir.

Modele ilişkin uyum iyiliği indekslerinin yeterlilik gösterdiği görülerek araştırmanın nihai modeli olarak Şekil 2'de yer alan modele de analiz sonlandırılmıştır.

Şekil 2 incelendiğinde Çocuk Sorumluluğu (Faktör 1) gizil değişkeni ve göstergeler (maddeler) arasındaki standartlaştırılmış parametre tahminlerinin $.50-.67$, Eşin önceliği (Faktör 2) gizil değişkeni ve göstergeleri arasındaki parametre tahminlerinin .57 .81 arasında ve son olarak da iş yaşamı sorunları (Faktör 3) gizil değişkeni ve göster- 


\section{Şekil 2}

Kadınlarda olası kariyer sonlandırma nedenleri ölçeği (KOKSNÖ) ikinci düzey DFA modeli

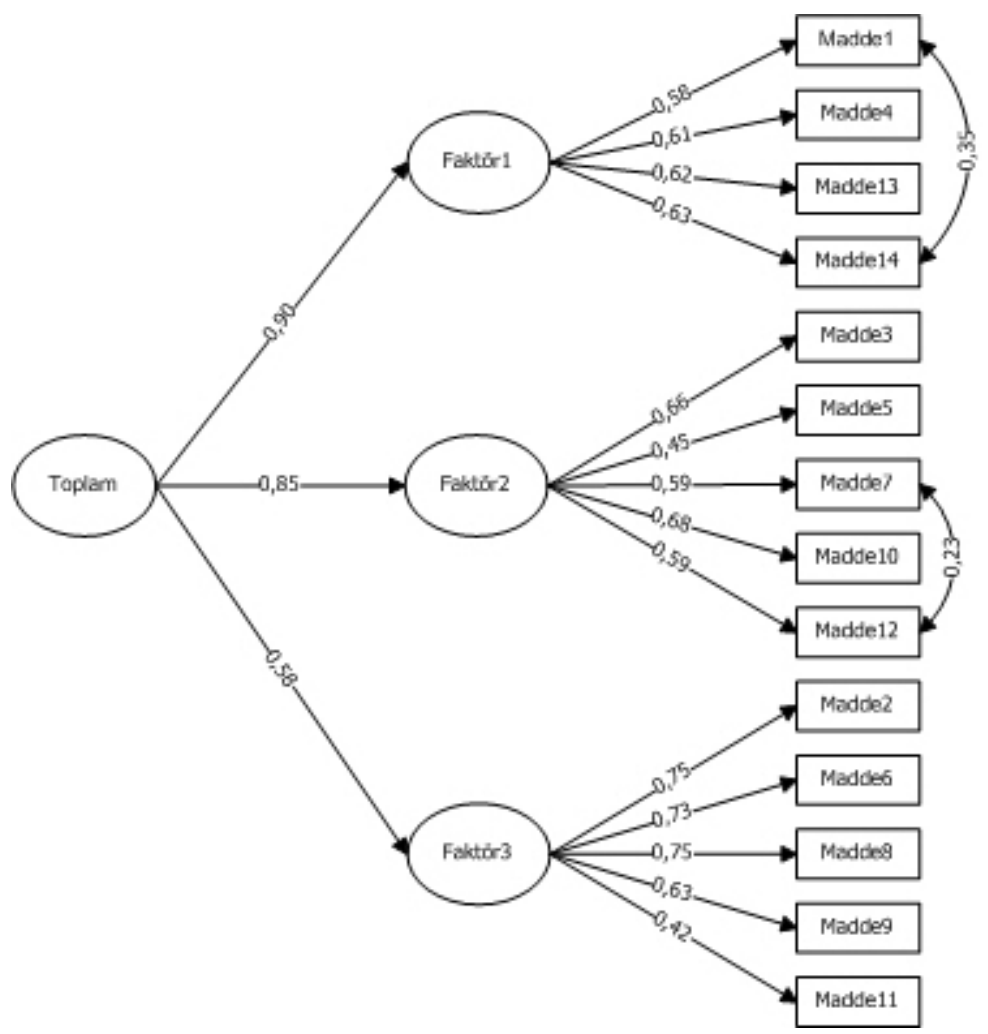

geleri arasındaki parametre tahminlerinin ise $.43-.82$ arasında olduğu görülmektedir. İkinci düzeyde olan modelin toplam gizil değişkeni ve göstergeleri olan alt değişkenleri arasındaki standartlaştırılmış parametre tahminlerinin faktör sirasıyla $.90, .85$ ve .58 olarak hesaplanmıştır. Üst düzeyde çıkan standartlaştırılmış parametre tahminlerinden dolayı ölçeğin alt boyutlarının toplamının alınabileceği kabul edilmiştir.

\subsection{Güvenirlik}

Kadınlarda olası kariyer sonlandırma nedenleri ölçeğinin (KOKSNÖ) güvenirlik çalışması Cronbach alfa iç tutarlılık katsayısı ve test tekrar test yöntemleri kullanılarak incelenmiştir. Çocuk sorumluluğu alt boyutunun Cronbach alfa iç tutarlılık katsayısı .76, eşin önceliği alt boyutunun .73, iş yaşamı sorunları boyutunun .75 ve ölçeğin toplamına ilişkin katsayı ise .84 olarak hesaplanmıştır. Ölçeğin test tekrar test güvenirlik çalışması Abant İzzet Baysal Üniversitesi, Eğitim Fakültesi, Rehberlik ve Psikolojik Danışmanlık anabilim dalında 3 . ve 4 . siniflara devam eden 32 bayan öğrenci üzerinden yürütülmüştür. Ölçeğin ilk uygulamasının ardından 2 hafta sonra ölçek tekrar aynı katılımcılara uygulanarak test tekrar test işlemi gerçekleştirilmiştir. Ölçeğin tüm alt boyutu ve toplamı için ilk ve ikinci uygulama arasında pozitif yönde anlamlı ilişkilerin olduğu bulunmuştur. Aşağıda test tekrar test işlemine ilişkin analiz sonuçları verilmiştir.

\subsection{Madde Analizi}

Kadınlarda olası kariyer sonlandırma nedenleri ölçeğinin (KOKSNÖ) geçerlik ve güvenirlik çalışmalarından sonra ölçeğin madde analizleri düzeltilmiş madde toplam 


\section{Tablo 3}

Kadınlarda olası kariyer sonlandırma nedenleri ölçeği (KOKSNÖ) test tekrar test sonuçları

\begin{tabular}{lccccc}
\hline & \multicolumn{2}{c}{ İlk uygulama } & \multicolumn{2}{c}{ Íkinci uygulama } & \\
\cline { 2 - 5 } & $\overline{\mathbf{x}}$ & ss & $\overline{\mathbf{x}}$ & ss & \multirow{2}{*}{} \\
\hline Çocuk sorumluluğu & 12,57 & 3,55 & 12,94 & 3,35 & $.77^{*}$ \\
Eşin önceliği & 19,47 & 3,74 & 17,85 & 3,10 & $.63^{*}$ \\
İş yaşamı sorunları & 19,78 & 3,83 & 18,97 & 3,12 & $.74^{*}$ \\
Toplam & 51,81 & 8,91 & 49,75 & 7,88 & $.75^{*}$ \\
\hline${ }^{\star} p<, 001$ & & & & &
\end{tabular}

korelasyonları ve alt/üst \%27'lik grupların madde puanları arasındaki farkların anlamlılık düzeyleri yöntemleri kullanılarak incelenmiştir. Yapılan madde analizi sonucunda ölçeğin madde toplam korelasyonlarının .42.56 arasında olduğu bulunmuştur. Ölçeğin toplam puaninda elde edilen \%27'lik alt ve üst grup maddeler farklarının tüm maddelerde anlamlı olduğu ve $t$ değerlerinin 6,30 $(p<, 001)$ ile 16,37 $(p<, 001)$ arasında olduğu gözlenmiştir. KOKSNÖ' nün madde anali- zine ilişkin sonuçlar tablo 4'te verilmiștir.

\section{Tartışma ve Sonuç}

Araştırma kapsamında yürütülen kadınlarda olası kariyer sonlandırma ölçeği (KOKSNÖ) geliştirme çalışması sonucunda 14 madde de üç alt boyutta ve toplam puanı alınabilen Likert tipi beşli derecelendirmeli (Hiç uygun değil, çok az uygun, kısmen uygun, oldukça uygun, tamamen uygun) bir ölçek oluşturulmuştur. Özbildirim tarzı (self

\section{Tablo 4}

Kadınlarda olası kariyer sonlandırma nedenleri ölçeğinin madde toplam korelasyonları ve $\% 27$ alt-üst grup farkına ilişkin $t$ testi değerleri

\begin{tabular}{|c|c|c|}
\hline & 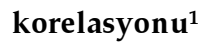 & $(\text { Alt } \% 27-U ̈ s t \% 27)^{2}$ \\
\hline Madde 1 & ,53 & 13,87 \\
\hline Madde 2 &, 52 & 12,28 \\
\hline Madde 3 &, 53 & 12,31 \\
\hline Madde 4 &, 50 & 11,14 \\
\hline Madde 5 & ,45 & 8,50 \\
\hline Madde 6 & ,43 & 11,68 \\
\hline Madde 7 &, 47 & 10,97 \\
\hline Madde 8 & ,46 & 12,04 \\
\hline Madde 9 &, 50 & 11,57 \\
\hline Madde 10 &, 57 & 16,37 \\
\hline Madde 11 & ,42 & 6,30 \\
\hline Madde 12 & ,49 & 11,78 \\
\hline Madde 13 &, 50 & 12,24 \\
\hline Madde 14 &, 56 & 14,24 \\
\hline
\end{tabular}

${ }^{1} n=357,{ }^{2} n_{1}=n_{2}=96, \mathrm{sd}=191,{ }^{*} p<.001$ 
report) olan ölçeğin geçerlik ve güvenirlik çalıșması ölçeğin kadınlarda olası kariyer sonlandırma nedenlerini belirleme de kullanılabilecek bir ölçme aracı olduğunu göstermektedir. Ölçeğin tüm maddeleri pozitif yöndedir. Bunun içinde cevaplayıcıların yanitları doğrudan toplanarak alt ölçeklere ve ölçeğin toplamına ilişkin puanlamalar yapılmaktadır. Ölçeğin birinci alt ölçeği olarak cevaplayıcının çocuk sahibi olmayı düşündüğünde ve çocuk sahibi olduğunda kariyerini sonlandırmaya yönelik görüşlerini içeren "çocuk sorumluluğu" dur. Bu alt ölçekte toplamda 4 madde bulunmaktadır (Madde1, Madde4, Madde13 ve Madde14). Çocuk sorumluluğu alt ölçeğinden alınabilecek en düşük puan 4, en yüksek puanda 20 'dir. Bu alt ölçekten alınan yüksek puan cevaplayıcının çocukla ilgili sorumluluklarından dolayı kariyerini sonlandırmaya yönelik eğilimin yüksek olduğunu, alınan düşük puan ise cevaplayıcının çocuk sorumluğu artmasında bile kariyerini sonlandırma eğiliminin düşük olduğunu göstermektedir. Ölçeğin ikinci alt boyutu olarak cevaplayıcının eşinin kariyeriyle ilgili önceliliklerinin kendi kariyerinden daha fazla önemsediğiyle ilgili görüşleri yer aldığı "eşin önceliği" boyutudur. Bu alt ölçekte toplamda beş madde (Madde3, Madde5, Madde7, Madde10 ve Madde12) bulunmaktadır. Ölçekten alınabilecek en düşük puan 5 'ken alınabilecek en yüksek puanda $25^{\prime}$ dir. Eşin önceliği boyutundan alınan yüksek puan cevaplayıcının evlendiğinde eşinin önceliklerini önemseyerek kariyerini sonlandırma eğiliminin yüksek olduğunu alınan düşük puan ise cevaplayıcının kendi kariyerini eşinin önceliklerine tercih edebileceğini göstermektedir. Ölçeğin son alt boyutu olan "iş yaşamı sorunları" boyutunda 5 madde bulunmaktadır (Madde2, Madde6, Madde8, Madde9 ve Madde11). Bu alt boyuttan al1nabilecek en düşük puan 5'ken alınabilecek en yüksek puan 25'dir. Bu alt boyuttan al1nan yüksek puan cevaplayıcının çalışma hayatındaki olası sorunlarla baş etmek yerine kariyerini sonlandırma eğilimi gösterebileceğini, alınan düşük puansa cevaplayıcının çalışma alındaki sorunlarla baş etme eğilimi göstererek kariyerine devam etmede çaba harcayacağını göstermektedir. İkinci düzey doğrulayıcı faktör analizi sonucuna göre ölçeğin tüm maddeleri toplanarak genel bir toplam elde edilebilecektedir. Ölçeğin toplamından alınabilinecek en düșük puan $14^{\prime}$ ken alınabilecek en yüksek puansa 70'dir. Ölçeğe ilişkin genel toplamın yüksek olması cevaplayıcının kariyer sonlandırmaya yönelik yüksek eğilimi olduğunu düşük puanın ise cevaplayıcının kariyer sonlandırmaya yönelik eğiliminin düşük olduğunu göstermektedir.

KOKSNÖ, Cook, Heppner ve O'Brien (2005)'nin kadınların kariyer örüntülerini temelinde etnik ve toplumsal cinsiyet rollerinin yerleştiğini savundukları ekolojik modelleri baz alınarak kariyer alanında çalışan psikolojik danışmanlar ve diğer uzmanların kullanımına yönelik geliştirilmiştir. Ölçek geliştirme çalışması göstermektedir ki ölçek işe alımda ve kariyer değerlendirme kullanılabilecek güçlü bir ölçektir. Ülkemizde kullanılan kariyer değerlendirme ve istihdama ilişkin ölçeklerinin hemen hepsinin Batı dünyasında yaşayan erkekler üzerinden geliştirildiği düşünüldügünde ölçeğin alandaki sorunların giderilmesinde bir katkı sağlayacağ ${ }_{1}$ düşünülebilir. Ancak uygulayıcılar ölçeğin kullanımında bir dizi sorunlarla karşılaşılabilir. Bu sorunların en olası olanı her kendini anlatma ölçeğinin değerlendirilmesinde yaşanabilen cevaplayıcıların ölçek maddelerine yanlı yanitlar vermesidir. Özer (2005) cevaplayıcılarının yanlı yanitlar vermesinin iki olası nedeni olduğunu vurgulamaktadır. Bunlardan ilki cevaplayıcının içten ve maddelerinin içeriğine katılma veya katılmama durumuna bakmaksızın genel kabule ya da ret edilmeye yönelik kalıplaşmış yanıtlar vermesidir. İkincisi ise cevaplayıcının kendini daha iyi ve ya daha kötü göstermeye yönelik cevaplar vermesidir (Bakınız; Özer, 2004). KOKSNÖ'nün profesyonel meslek adayı kadınlarda kullanılabilineceği düşünüldüğü için her iki cevaplayıcı yanlılığının ölçeğin iç ve dış geçerliliğini tehdit edeceği düşünülmektedir. Bunun içinde uygulayıc1larının ölçeği dolgu maddelerle kullanması 
ya da madde sayısı yüksek olan kişilik envanterlerinin içine gömülü maddeler olarak kullanması önerilebilir. Ayrıca ölçek her ne kadar lisans düzeyinde eğitim almış veya almakta olan kadınların olası kariyer sonlandırma nedenlerini belirlemeye yönelik geliştirilse de daha düşük eğitim seviyesinde olan kadınlarda da kullanılabileceği düşünülmektedir. Bunun için ileri ki araştırmalar da profesyonel mesleği olmayan kadınlarda da yürütülecek araștırmalarda ölçeğin kullanılarak güvenirlik düzeyinin incelemesinde fayda görülmektedir. Bu çalıșmanın en önemli sınırlılığı, örneklemin yalnızca henüz iş yaşamına girmemiş olan bireylerden oluşmasıdır. Dolayısıyla is yașamına devam eden örneklem üzerinde de psikometrik özelliklerinin incelenmesi yerinde olacaktır. Çalışmanın bir diğer sınırlılığı ise ölçeğin geçerliliğini belirlemeye yönelik olarak kullanilan yöntemlerden benzer ölçek geçerliğinin ölçülmemiş olmasıdır. Bundan sonra yapılacak çalışmalarda kariyer sonlandırma ve iş yaşamıyla ilgili geçerlik ve güvenirliği belirlenmiş ölçekler kullanılarak benzer ölçek geçerliği ortaya konulabilir. Sonuç olarak KOKSNÖ'nün Türk kültürü için, kariyer sonlandırma nedenlerini çeşitli boyutlarıyla geçerli ve güvenilir bir biçimde ölçebilen bir ölçek olduğu söylenebilir.

\section{Kaynaklar}

Aytaç, S. (2001). Örgütsel davranış açısından kişiliğin önemi. İş Güç Endüstri İlişkileri ve İnsan Kaynakları Dergisi, 3(1).

Aytaç, S. ve Bayram, N. (2001). Üniversite gençliğinin iş ve eş seçimindeki etkin kriterlerin analitik hiyerarşi süreci (Ahp) il analizi. İş Güç Endüstri İlişkileri ve İnsan Kaynakları Dergisi, 3(1).

Aytaç, S. ve Keser, A. (2002). İşsizliği çalışan bireyler üzerindeki etkisi: İşsizlik kaygisı İş Güç Endüstri İlişkileri ve İnsan Kaynakları Dergisi, 4(1).

Bierema, L.L. (1998). A Synthesis of Women's Career Development Issues. New Directions For Adult And Continuning Education, 80, 95-103.

Brumit Kropf, M. (1998). Women's Development and Part-Time Arrangements. New Directions For Adult Countinuing Education, 80, 43-51.

Büyüköztürk, Ş. (2007). Sosyal Bilimler için Veri Analizi El Kitabı. İstatistiki Araştırma Deseni SPSS Uygulamaları ve Yorum. (8. Bask1). Ankara: PegemA Yayincilik.

Clark, L. A. ve Watson, D. (1995). Constructing validity: Basic issues in objective scale development. Psychological Assessment, 7(3), 309-319.

Coakes, S. J. (2005). SPSS: Analysis without anguish: Version 12.0 for Windows. Melbourne: John Wiley and Sons.

Cook, E. P., Heppner, M. J. ve O’Brien, K. M. (2002). Career development of women of color and white women: Assumptions, conceptualization, and interventions from an ecological perspective. The Career Development Quarterly, 50, 291305. 
Cook, E. P., Heppner, M. J. ve O’Brien, K. M. (2005). Multicultural and gender influences in women's career development: An ecological Perspective. Multicultural Counseling and Development, 33, 165-179.

DeVellis, R. F. (2003). Scale development: Theory and applications (2. Bask1). California: Sage publications.

Field, A. (2005). Discovering Statistics Using SPSS. Londra: Sage Publications.

Gybers, N.C., Heppner, M.J. ve Johnston, J.A. (1998). Career Counseling. Process, Issues, and Techniques. Massachusetts: Allyn and Bacon.

Hair, J. F., Black, B., Babin, B., Anderson, R. E., ve Tatham, R. L. (2006). Multivariate Data Analysis. Upper Saddle River: Prentice Hall.

Hawley McWhiter, E. (1997). Perceived barriers to education and career: Ethnic and gender differences. Journal of Vocational Behaviour, 50, 124-140.

Herr, E.L. ve Cramer, S.H. (1996). Career Guidance and Counseling Through the Lifespan: Sytematic Approaches (5. Bask1). New York: Harper Collins College Publihers.

Hewlett, S. A. ve Luce, C. B. (2000). Çıkışlar ve Girişler. Yetenekli kadınları başarı yolunda tutmak. İçinde: Yetenek Yönetimi, Harvard Business Review. İstanbul: Türkiye Metal Sanayicileri Sendikası.

Kline, R. B. (2005). Principles and practice of Structural Equations Modeling. New York: Guilford.

Marks, G. ve Houston, D.M. (2002). The Determinants Of Young Women's Intentions About Education, Career Development And Family Life. Journal Of Education And Work, 15(3), 321-336.
Meyers, L. S., Gamst, G. ve Guarino, A.J. (2006). Applied Multivariate Research. Design and Interpretation. California: Sage Publication Inc.

Mott, V. W. (1998). Women's career development in midlife and beyond. Directions for Adult and Contiunuing Education, 80, 25-33.

Noar, S. M. (2003). The role of structural equation modeling in scale development. Structural Equation Modeling: A Multidisciplinary Journal, 10(4), 622647.

Oğuzlar, A. (2003). Veri ön işleme. Erciyes Üniversitesi İktisadi ve İdari Bilimler Fakültesi Dergisi, 21, 67-76

Schumacker, R. E., ve Lomax, R. G. (2004). A Beginner's Guide to Structural Equation Modeling. New Jersey: Lawrence Erlbaum Ass.

Özer, A. (2004). Bankacılık sektöründe kişiliğin değerlendirilmesi. Yayınlanmamış doktora tezi, Ankara: Hacettepe Üniversitesi.

Özer, A. (2005). İyi izlenim ölçeğinin hazırlanması. Abant İzzet Baysal Üniversitesi Eğitim Fakültesi Dergisi, 5(1), 105-122.

Pınarcıoğlu, N. Ş. (2006) Kentlerde kadınların işgücü ve istihdama katılım sorunları: İzmit örneği. Kocaeli Üniversitesi, Sosyal Bilimler Enstitüsü, Yayınlanmamış Yüksek Lisans Tezi.

Raykov, T. ve Marcoulides, G. A. (2006). A first course in structural equation modeling. (2. Baskı). New Jersey: Lawrance Erlbaum Ass.

Rosenbloom, J.L., Ash, R.A., Dupont, B. ve Coder, L. (2008). Why Are So Few Women Information Technology? Assessing The Role Of Personality In Career Choices. Journal of Economic Psychology, 29(4), 543-554. 
Schreiber, P.J. (1998). Women's Career Development Patterns. New Directions For Adult And Continuning Education, 80, 5-13.

Sharf, R. S. (2002). Appliying Career Development Theory to Counseling. California: Brooks and Cole Pub.

Smart, R. M. (1998). Career Stages In Australian Professional Women: A Test Of Super's Model. Journal of Vocational Behaviour, 52, 379-395.

Şimşek, Ö. F. (2008). Yapısal Eşitlik Modellemesine Giriş: Temel İlkeler ve LISREL Uygulamaları. Ankara: Ekinoks Yayıncilık.

Tabachnick, B. G., ve Fidell, L. S. (2007). Using Multivariate Statistics (5. Bask1). Boston: Allyn and Bacon.

TÜİK. (2008). Türkiye İstatistik Kurumu. Hane Halkı İş Gücü Anketi Sonuçları. İnternetten 28.Ocak.2009 tarihinde www.die.gov.tr adresinden alınmıştır.

Wentling, R. M. (1998). Work and Family Issues: Their Impact on Women's Career Development. New Directions For Adult And Continuning Education, 80, 15-24.

Worthington, R. L. ve Whittaker, T. A. (2006). Scale development research: A content Analysis and recommendations for best practices. The Counseling Psychologist, 34, 806-838. 


\section{Kadınlarda olası kariyer sonlandırma nedenleri ölçeği}

\begin{tabular}{|c|c|c|c|c|c|c|}
\hline & & 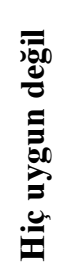 & 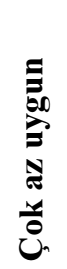 & 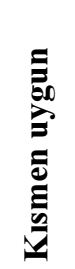 &  & 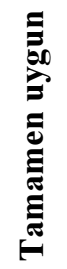 \\
\hline 1 & Çocuk sahibi olmayı düşündüğümde işimi bırakırım & & & & & \\
\hline 2 & $\begin{array}{l}\text { Meslek hayatımda çalışma koşullarının kadınlar için uygun } \\
\text { olmadığını düşündügüumde işimi bırakırım }\end{array}$ & & & & & \\
\hline 3 & Eşim istemezse terfi etmekten vazgeçebilirim & & & & & \\
\hline 4 & Kadının çocukları işinden önce gelir & & & & & \\
\hline 5 & Eşimin iş yerindeki pozisyonu benden üstte olmalıdır & & & & & \\
\hline 6 & $\begin{array}{l}\text { Meslek hayatımda cinsel ayrımcılıkla karşılaşırsam işimi } \\
\text { bırakırım }\end{array}$ & & & & & \\
\hline 7 & $\begin{array}{l}\text { Evlendiğimde eşimin işiyle ilgili öncelikler benimkinden } \\
\text { önde gelecektir }\end{array}$ & & & & & \\
\hline 8 & $\begin{array}{l}\text { İş yerimde kadınların işle ilgili görüşleri daha az } \\
\text { önemsenirse işimi bırakırım }\end{array}$ & & & & & \\
\hline 9 & $\begin{array}{l}\text { İş ortamımdaki huzursuzluklar işimi bırakmama neden } \\
\text { olacaktır }\end{array}$ & & & & & \\
\hline 10 & Kadının eşi işinden önce gelir & & & & & \\
\hline 11 & $\begin{array}{l}\text { Çalışırken erkek meslektaşlarımdan daha çok } \\
\text { sorumluluğum olursa bu durum işimi bırakmama neden } \\
\text { olacaktır }\end{array}$ & & & & & \\
\hline 12 & İş gereği taşınmamız gerekse öncelik eşime aittir & & & & & \\
\hline 13 & $\begin{array}{l}\text { Sonucunda çocuğuma daha az zaman ayıracaksam } \\
\text { mesleğimde bir üst kademeye çıkmaktan vazgeçerim }\end{array}$ & & & & & \\
\hline 14 & Çocuk sahibi olduğumda işimi bırakırım & & & & & \\
\hline
\end{tabular}

